Abstracta Iranica Abstracta Iranica

Revue bibliographique pour le domaine irano-aryen

Volume 28 | 2007

Comptes rendus des publications de 2005

\title{
Maqālāt-e Hānrī Corban. Tehrān, Entešārāt-e haqīqat, 1384/2005, 447 p. [Articles sur Henry Corbin]
}

Mohammad Ali Tavoussi

\section{(2) OpenEdition}

1 Journals

Édition électronique

URL : http://journals.openedition.org/abstractairanica/12642

DOI : $10.4000 /$ abstractairanica. 12642

ISSN : 1961-960X

Éditeur :

CNRS (UMR 7528 Mondes iraniens et indiens), Éditions de l'IFRI

\section{Édition imprimée}

Date de publication : 15 mai 2007

ISSN : 0240-8910

Référence électronique

Mohammad Ali Tavoussi, « Maqālāt-e Hānrī Corban. Tehrān, Entešārāt-e haqīqat, 1384/2005, 447 p.

[Articles sur Henry Corbin] », Abstracta Iranica [En ligne], Volume 28 | 2007, document 270, mis en ligne le 18 septembre 2007, consulté le 25 septembre 2020. URL : http://journals.openedition.org/ abstractairanica/12642 ; DOI : https://doi.org/10.4000/abstractairanica.12642

Ce document a été généré automatiquement le 25 septembre 2020.

Tous droits réservés 


\title{
Maqālāt-e Hānrī Corban. Tehrān, Entešārāt-e haqīiqat, 1384/2005, 447 p. [Articles sur Henry Corbin]
}

\author{
Mohammad Ali Tavoussi
}

Cet ouvrage comprend la traduction en persan de 17 articles sur professeur Henry Corbin (1903-1978), réunis à l'issue du colloque organisé en novembre 2003 (Ādar 1382) à l'occasion de la célébration du centième anniversaire de la naissance d'Henry Corbin sous les auspices du Collège de Philosophie d'Iran en collaboration avec l'Institut Français de Recherche en Iran. Certains de ces articles sont les préfaces écrites par Corbin pour des ouvrages de grands philosophes et mystiques iraniens (Al-Mašă $\bar{c}^{\iota}$, Šarh$e$ šațhiyyāt (les Paradoxes des soufis), Mașqal ol-șafā, Jāme ol-asrār va manba' ol-anvār (La philosophie chiite, somme des doctrines ésotériques, traité de la connaissance de l'être) etc...), des chapitres des ouvrages de Corbin (Histoire de la philosophie islamique; En Islam iranien et Traité des Compagnons-chevaliers) et enfin certaines interventions et conférences qu'il avait présentées dans des universités, des instituts de recherches scientifiques et culturels et des colloques spécialisés en Iran et à l'étranger et dont les résumés sont réunis dans ce livre. Ce recueil qui embrasse une période de cinquante ans (1958 à 1993), représente les activités de recherche d'Henry Corbin en Iran.

\section{INDEX}

Thèmes : 7. Islam 


\section{AUTEURS}

MOHAMMAD ALI TAVOUSSI

IRIP - Téhéran 